DOI 10.31651/2524-2660-2020-4-218-224

ORCID 0000-0002-9376-4346

\title{
СЕРДЮК Зоя Охексіїна,
}

кандидатка педагогічних наук, доцентка кафедри математики та методики навчання математики,

Черкаський національний університет імені Богдана Хмельницького e-mail:serdyuk_z@ukr.net

ORCID 0000-0002-5691-8270

\section{КОСТРУБ Юмія Микомаївна,}

студентка 2 курсу ОС "Магістр" ННI інформаційних та освітніх технологій,

Черкаський національний університет імені Богдана Хмельницького

УДК: 373.5.091.33-027.22::51]:004.77 Google (045) e-mail: tkostrubj@gmail.com

\section{ВИКОРИСТАННЯ ІНФОРМАЦІЙНО-КОМУНІКАЦІЙНИХ ТЕХНОАОГІЙ У НАВЧАННІ MATEMATИKИ HA OCHOBI CEPBICIB GOOGLE}

Описано способи використання основних інформаиійно-комунікаиійних технологій, на основі сервісів Google, у навчанні математики, обтрунтовано необхідність використання даних технологій на уроках та позашкільній діяльності з математики.

Досліджено вплив використання інформаиійно-комунікаиійних технологій на пізнавальну та навчальну діяльність учнів. Подано методи- чні рекомендаиії для вчителя шодо застосування інформаиійно-комуніка-иійних технологій у викладанні математики.

Ключові слова: сайт; інформаиійнокомунікаиійні технологї (IKT); веб-сервіси; хостинг; діаграми; публікаиії; навчання математики. 
Постановка пробцеми. Розвиток освіти в Україні нині спрямований на необхідність пристосування учнів до умов сучасного цифрового суспільства. Практичний напрям математичної освіти значно підвищується завдяки впровадженню інформаційно-комунікаційних засобів у навчання математики. Переплетення математики 3 інформатикою створює нові додаткові можливості у викладанні математики в сучасній школі.

Аналіз останніх досліджень і публікацій. Різні проблеми IKT навчання досліджували К. Баханова, П. Грабовський, В. Гузєєва, Т. Добриніна, А. Єршов, О. Мерзиикін, О. Пометун, $\Lambda$. Пироженко, С. Сисоєва, Н. Суворова, В. Хрипун, Г. Черненко та інші.

Деякі окремі аспекти використання IKT навчання окремих дисциплін висвітлені у працях: Р. Абдулова, Н. Коломієць, І. Куришевої, О. Склярової, Н. Шолохової, М. Юсупової, та інших. До інтерактивного навчання математики звертаються у своїх працях науковці: I. Акуленко, $\Lambda$. Ампілого-

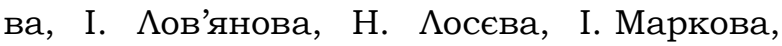
Н. Непомняща, А. Панова, В. Прокопенко, Г. Скинець, Н. Тарасенкова, С. Федосєєв, Н. Харіна та інші.

Мета статті - обгрунтувати необхідність використання інформаційнокомунікаційних технологій, зокрема, сервісів Google, на уроках математики у школі, дослідити вплив інформаційнокомунікаційних технологій на творчий розвиток учнів, увагу та пізнавальну діяльність, розширити творчі та професійні можАивості учителя, визначити методичні рекомендації щодо застосування інформаційно-комунікаційних технологій у вивченні математики.

Викцад основного матеріалу. ДАя успішної участі в сучасному суспільному житті особистість повинна володіти певними прийомами математичної діяльності та навичками ix застосувань до розв'язування практичних задач.

Навчання математики полягає у забезпеченні свідомого і міцного оволодіння системою математичних знань, навичок $\mathrm{i}$ умінь. Значні вимоги до володіння математикою ставлять сучасний ринок праці, отримання якісної професійної освіти, продовження освіти на наступних етапах. Тому одним із головних завдань курсу математики є забезпечення умов дмя досягнення кожним учнем практичної компетентності [1;2].
Головними завданнями викладання математики в школі є формування в учнів наукового світогляду, розуміння ролі математики у пізнанні дійсності, оволодіння учнями математичною мовою, розвитку могічного та абстрактного мислення. Дия реалізації цих завдань потрібна якісна підготовка вчителя, правильна організація навчального процесу, використання, відповідних сучасному суспільству, методів [3; 4].

Одним із найважливіших засобів реалізації завдань навчання математики $\epsilon$ встановцення міжпредметних зв'язків математики з іншими предметами [2; 3]. Особливої уваги заслуговує встановцення зв'язків між математикою та інформатикою - двома освітніми галузями, які $є$ визначальними у підготовці особистості до життя у постіндустріальному, інформаційному суспікьстві. Широке застосування інформаційно-комунікаційних засобів у навчанні математики доцільне дмя проведення математичних експериментів, практичних занять, інформаційного забезпечення, візуального інтерпретування математичної діяльності, проведення досліджень [2; 4].

Стрімкий розвиток Інтернет-технологій створює необхідне підгрунтя до появи нових навчальних сервісів. Мережеві моделі навчання розвиваються стрімкими темпами саме завдяки мережевим технологіям.

Сервіси Google сьогодні є популярним інструментом спілкування, обміну думками та отримання інформації. Сервіси Google не $и$ спе сприяють формуванню умінь працювати 3 веб-додатками, а й можливість використання даних сервісів в подальшій професійній діяльності.

Використання такого середовища як Google значно підвищує інтерес учнів до навчання, створює умови для саморозвитку, активізує пізнавальну діяльність, формує вміння сприймати та обробляти великі масиви інформації, розвиває спостережливість, сприяє розвитку перцептивної уваги, формує компетентність щодо пошукової та науково-дослідної роботи. Використовуючи сервіси Google, викладачі та учні отримують більше інструментів дия спільної роботи в навчальному процесі: створення вебсайтів, ведення блогів, виконання проектів у групах, проведення мекцій та семінарів дистанційно тощо [5, с. 21].

Виділяють наступні переваги використання сервісів Google перед іншими видами мережевих технологій 
1. Висока функціональність та надійність, зручний україномовний інтерфейс. Способи комунікації та оприлюднення інформації в цьому середовищі доступні дмя опанування бікьшості користувачів. Цьому сприяє як зручність та зрозумілість системи, так і активний та тривалий досвід іï використання.

2. Індивідуальний доступ до ресурсів $\mathrm{i}$ сервісів, значний обсяг дискового (хмарного) простору, який надається користувачеBi.

3. Можливість формування груп і підрозділів користувачів. Форуми, опитування, голосування, коментарі, підписки, відправлення персональних повідомлень забезпечують широкі можливості дмя спільної роботи.

4. Інтеграція з іншими програмними засобами навчального закладу, можливість використання з мобільних пристроїв.

5. Щоб використовувати сервіси Google, достатньо підключення до Інтернету, браузера та будь-якої вільно розповсюджуваної операційної системи або мобікьного пристрою.

На часі $є$ створення сайту математики у школі. Використання такого сайту потрібно щоб посилити інтерес учнів до вивчення математики, спонукати учнів до самостійної роботи. За допомогою такого сайту у вчителя з'являться додаткові можливості урізноманітнити способи та методи викладання предмету, проводити додаткові факультативи, конкурси, тести, контрольні та самостійні роботи. Математичний сайт - це зручний засіб комунікації вчителя з учнями в період канікул, карантину, введення дистанційного навчання, а також чудовий спосіб додаткового зв'язку учителя з батьками.
На сайті є можливість розміщувати огомошення стосовно проведення математичних заходів, цікаві історії та факти з математики, створювати різні форми структурованих завдань дмя всіх класів. Доступ до сайту можливий $з$ будь-якого пристрою потрібно тільки підкАючення до Інтернету та зареєстрований акаунт (обліковий запис) Google.

Одним із швидких та зручних засобів створення такого сайту є конструктор від компанії Google - Google Sites. Google Sites використовує для формування контенту сторінок сайту, переважно, функціональність інших веб-сервісів Google: документи, таблиці, карти, презентації, діаграми, форми, публікацію відео з хостингу YouTube, а також невелику кількість додаткових базових елементів на кшталт роздільника, кнопки, зображення i, власне, тексту. Можна також додати свій HTML-код, що потенційно розширює можливості за рахунок інтеграції можливостей веб-сервісів, які не мають відношення до екосистеми Google [6, с. 223].

Дизайн сайту в Google Sites налаштовується в меню Додаткові дії - Керування сайтом - Оформлення сайту. Для створення комфортного дизайну в Google Sites $€$ спеціальні шаблони, які можна використовувати за призначенням сайту: портфоліо учня, робоча сторінка вчителя, сайт дия довідок, подія.

Служба Google Sites дає змогу безкоштовного створення сатів на безкоштовному хостингу. Обмеження на розмір сайту -100 МБ. Google Sites зрозумілі дия новачків, навіть якщо у вас зовсім не має досвіду.

Приклади розробки сайту подано на рисунках 1-4.
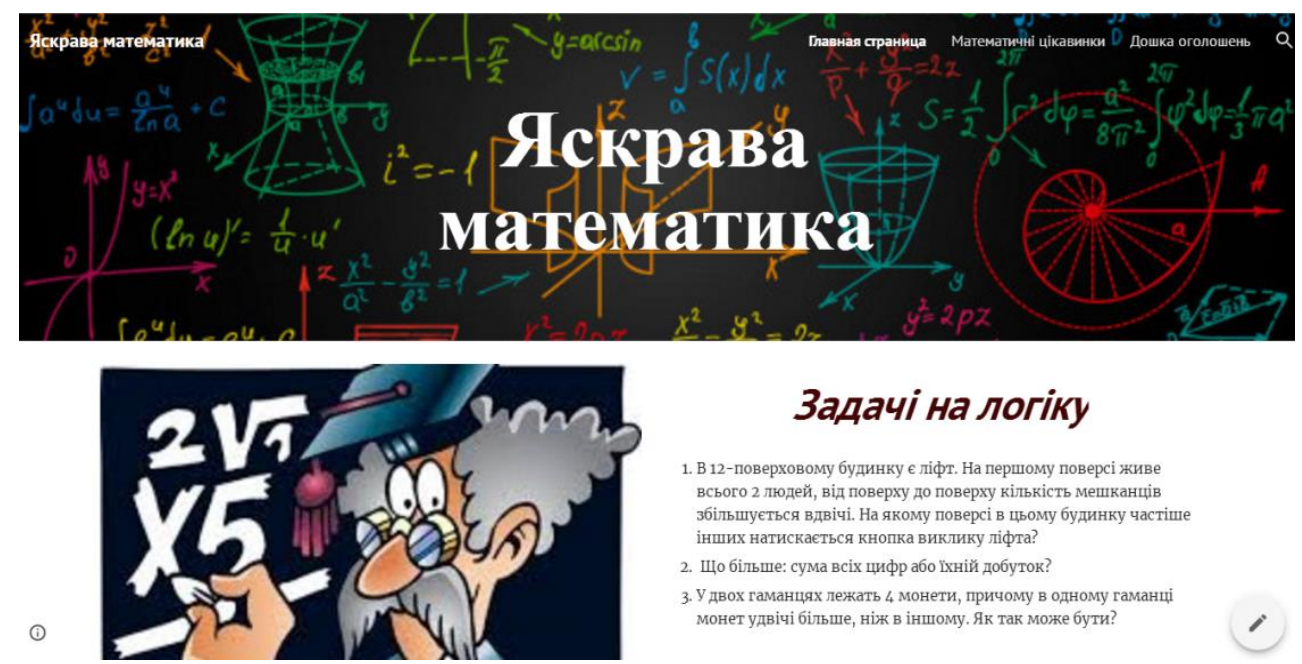

\section{Задачі на логіку}

1. В 12-поверховому будинку $є$ ліфт. На першому поверсі живе всього 2 людей, від поверху до поверху кількість мешканців збільшуеться вдвічі. На якому поверсі в цьому будинку частіше інших натискаеться кнопка виклику ліфта? 2. Що більше: сума всіх цифр або іхній добуток?

3. У двох гаманцях лежать 4 монети, причому в одному гаманщ

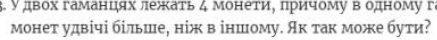

Рис. 1 


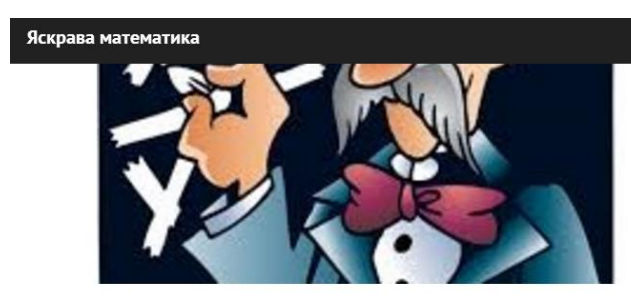

3. Удвох гаманцях лежать 4 монети, причому в одному гаманці

монет удвічі більше, ніж в іншому. Як так може бути?

А ти знаєш відповідь?

$$
\begin{gathered}
11 \times 11=4 \\
22 \times 22=16 \\
33 \times 33=?
\end{gathered}
$$

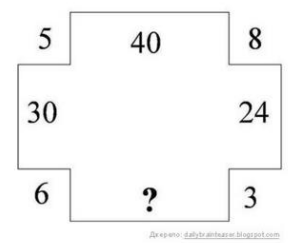

\begin{tabular}{|c|c|c|}
\hline 6 & 5 & 12 \\
\hline 12 & 15 & 36 \\
\hline 36 & 60 & 144 \\
\hline 144 & 300 & $?$ \\
\hline
\end{tabular}

Рис. 2
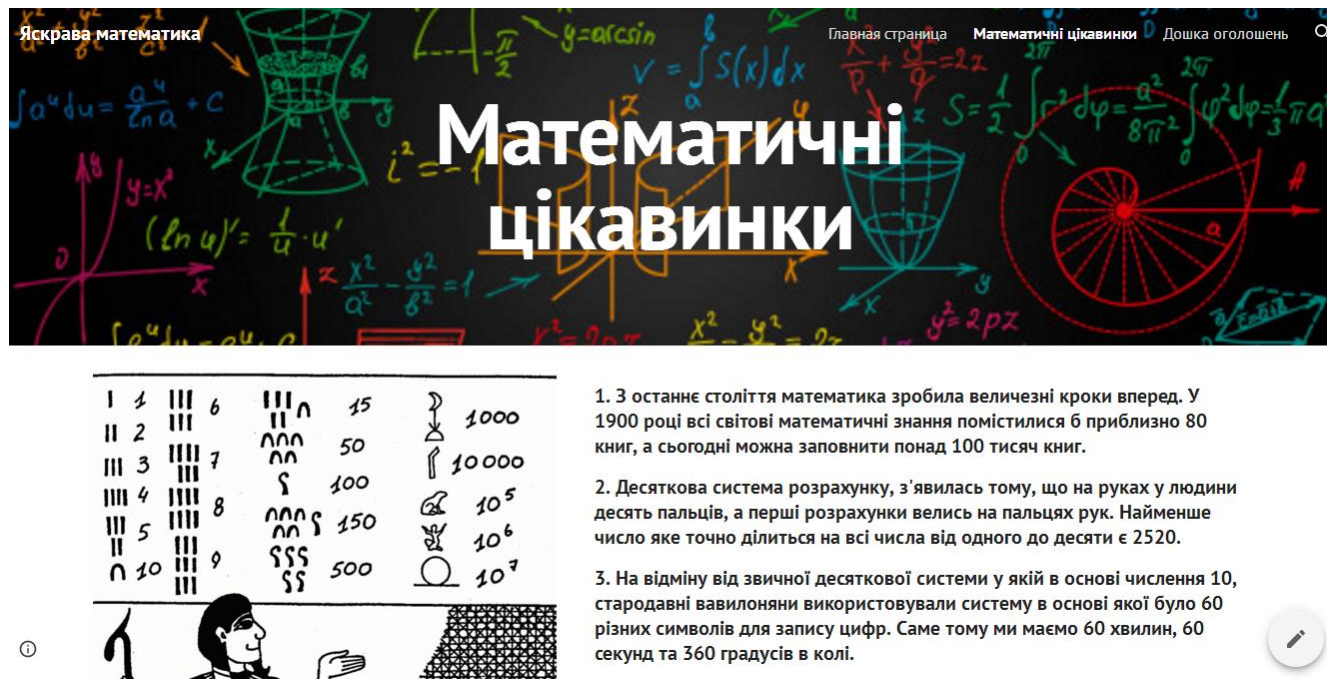

1. 3 останнє століття математика зробила величезні кроки вперед. У 1900 році всі світові математичні знання помістилися 6 приблизно 80 книг, а сьогодні можна заповнити понад 100 тисяч книг.

2. Десяткова система розрахунку, з'явилась тому, що на руках у людини десять пальців, а перші розрахунки велись на пальцях рук. Найменше число яке точно ділиться на всі числа від одного до десяти є 2520 .

3. На відміну від звичної десяткової системи у якій в основі числення 10 , стародавні вавилоняни використовували систему в основі якої було 60 різних символів для запису цифр. Саме тому ми маємо 60 хвилин, 60 секунд та 360 градусів в колі.

Рис. 3

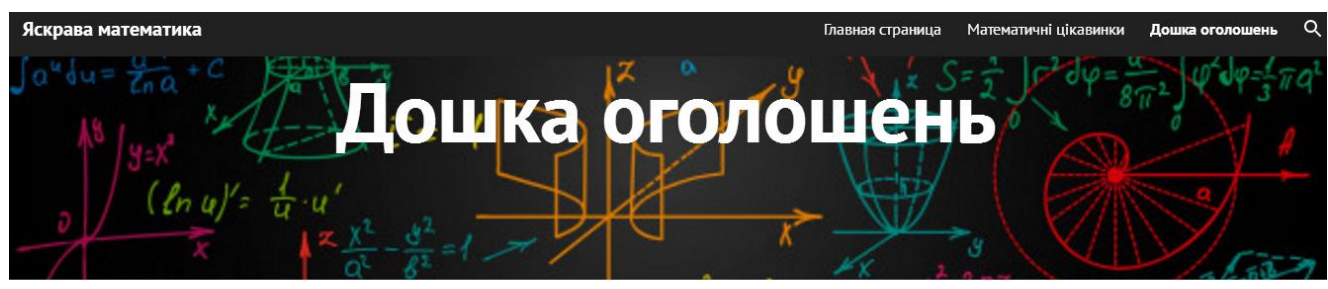

\section{Увага конкурс!}

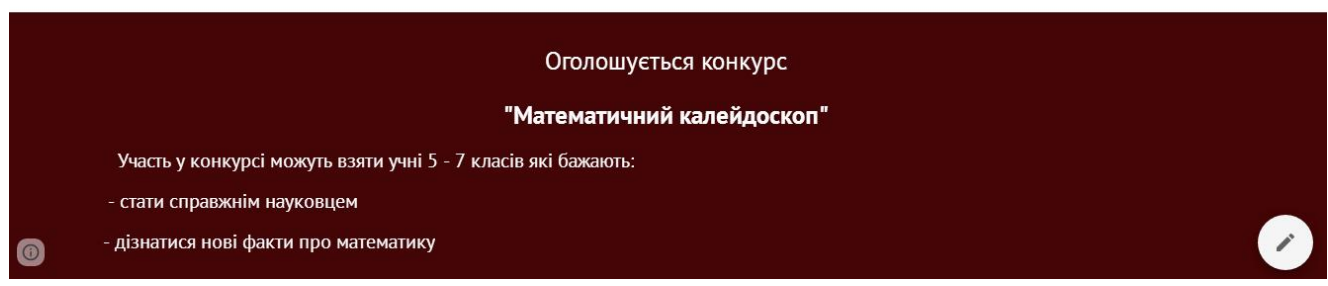

Рис. 4

ДАя заповнення сайту також можна скористатися розробками компанії Google. На свій сайт ви можете звантажити будь який текст, таблицю, презентацію або форму опитування використовуючи Google Docs, а також використати велику кімькість гаджетів із iGoogle
Наприклад використання Google-форм дає можливість проводити оцінювання та контроль самостійної роботи учнів, створювати опитування, анкети, тести для дистанційної перевірки знань, форми для реєстрації в навчальних та виховних заходах.

Приклади використання Google-форм подані на рисунках 5 і 6. 


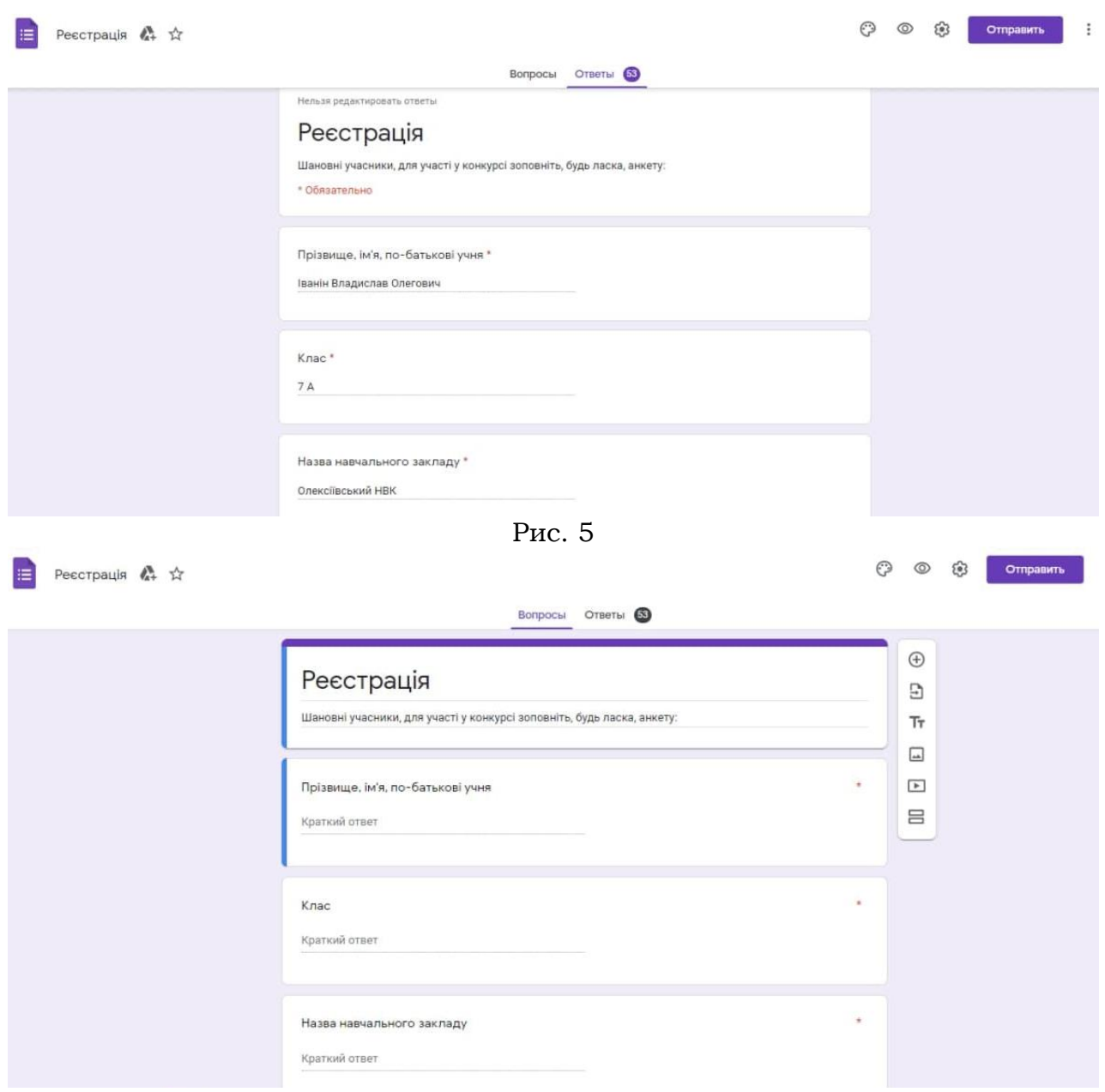

Рис. 6

Користувачам Google також доступне віртуальне сховище даних Google Drive. Це так званий диск на якому можна організувати власний робочий простір. Він дає можАивість організувати спільну роботу, наприклад вчителю з учнями, декільком класам, творчим групам. На диску є можливість створювати спільно доступні папки в яких можна зберігати, видаляти, додавати різні документи та файли [7, с. 108; 8].

Одним із найважливіших сервісів Google дия навчання $є$ Google Class. Адже саме в Google Class $€$ можливість організувати звичний навчальний процес, знаходячись в будь-якому місці, через інтернет. Викладач створює кАас по предмету в який додаються учні. В клас можна додавати завдання, тематичні обговорення, проводити тестування, контрольні та самостійні роботи. Повідомлення про створені завдання надходять учням на електронну пошту. Виконувати завдання можна як он-лайн в Google Docs, так і в оф-майн режимі, використовуючи будь-які зручні дмя вас програми.

В панелі вчителя у реальному часі оновАюється список виконаних робіт, їх можна переглянути, перевірити, написати коментар, поставити оцінку.
Висновки i перспективи подамьших досміджень. Головні переваги пропонованих технологій полягають в тому, що вони дозволяють інформатизувати процес навчання математики, більш відповідають вимогам сучасної школи в порівнянні 3 класно-урочною модемлю навчання. Вчитель, застосовуючи технології сервісів Google, отримує потужний інструмент дмя модернізації процесу освіти і виховання учнів на уроках математики.

Активна робота 3 використанням IKT формує в учнів більш високий рівень самоосвітніх навичок і вмінь, аналізу та структурування отриманої інформації. При цьому нові засоби навчання дозволяють органічно поєднувати інформаційнокомунікативні, особистісно - орієнтовані технології з методами творчої та пошукової діяльності. Сьогодні впровадження комп'ютерних технологій у навчальний процес $\epsilon$ невід'ємною частиною шкільного навчання. Загальновизнано, що використання комп'ютерних технологій в освіті неминуче, оскільки істотно підвищується ефективність навчання, якість знань і умінь [9, c. 109].

Крім того, впровадження засобів інформаційно-комунікаційних технологій у навчанні математики спрямоване на покращення інтенсивності процесу навчання, 
реалізацію ідей, вдосконалення форм і методів організації навчального процесу, що забезпечують перехід від механічного засвоєння математичних знань до оволодіння ними, уміннями самостійно набувати нових знань.

Отже, в цілому, інформаційно-комунікаційні технології в навчанні математики, зокрема сервіси Google є виключно корисною та плідною навчальною технологією, завдяки інтерактивності, гнучкості й інтеграції різноманітних типів мультимедійної навчамьної інформації, а також завдяки можливості врахування індивідуальних особливостей учнів та сприяння підвищенню їх мотивації під час вивчення математики. Інформаційно-комунікаційні засоби навчання $є$ перспективним i високоефективним інструментом, що дозволяє надавати інфрормацію у більшому обсязі, ніж традиційні джерела інформації у тій послідовності, що відповідає могіці пізнання. Завдяки цій технології можна підняти процес навчання математики на якісно новий рівень.

\section{Список бібліографічних посимань}

1. Навчальна програма з математики для учнів 10-11 класів (початок вивчення на поглибленому рівні $з$ 8 класу) загальноосвітніх навчальних закладів (Профімьний рівень) URL: https://mon.gov.ua/sto rage/app/media/zagalna\%20serednya/programy10-11-klas/2018-2019/matematika-profilnijrivenfinal.docx (дата звернення: 08.10.2020).

2. Навчальна програма з математики (А^гебра і початки аналізу та геометрія) для учнів 10-11 класів загальноосвітніх навчальних закладів (рівень стандарту) URL: https://mon.gov.ua/storage/app/medi a/zagalna\%20serednya/programy-10-11-klas/20182019/matematika.-riven-standartu.docx (дата звернення: 08.10.2020).

3. Навчальна програма з математики дия учнів 10-11 класів загальноосвітніх навчальних закладів (профільний рівень). URL: https://mon.gov.ua/sto rage/app/media/zagalna $\% 20$ serednya/programy10-11-klas/2018-2019/matematika-pogliblrivenfinal.docx (дата звернення: 08.10.2020).

4. Інформатика навчальна програма вибірковообов'язкового предмету для учнів 10-11 класів загальноосвітніх навчальних закладів (рівень стандарту) URL: https://mon.gov.ua/storage/app/media /zagalna\%20serednya/programy-10-11-klas /20182019/informatika-standart-10-11.docx (дата звернення: 08.10.2020).

5. Войтович Н.В., Найдьонова А.В. Використання хмарних B54 технологій Google та сервісів web 2.0 в освітньому процесі. Методичні рекомендації. Дніпро: Дніпровський центр ПТОТС, 2017. 113 с.

6. Сойчук Р.В. Інформаційно-комунікаційні технології у виховному процесі та сучасне підростаюче покоління: погляд на проблему. Інноватика у ви хованні, 2016. Вип. 4. С. 220-230.

7. Сейдаметова 3.С., Сейтвелиева С.Н. Облачные сервисы в образовании. Информаиионные технологии в образовании, 2011. № 9. С. 105-111.

8. Каштан Н.Б. Використання хмарних технологій в освітньому процесі сучасного навчального закладу. Оновлення змісту, форм та методів навчання $i$ виховання в закладах освіти, 2016. Вип. 13(2). С. 135-137.

9. Кадемія М.Ю., Шахіна І.Ю. Інформаційнокомунікаційні технології в навчальному процесі: навчальний посібник. Вінниця: Планер, 2011. 220 с.

\section{References}

1. Syllabus in Mathematics for the pupils of the 10-1 $11^{\text {th }}$ grades (the beginning of studying at the advanced level since $8^{\text {th }}$ grade) of the general education institutions (Advanced level). Retrieved 08.10.2020, from https://mon.gov.ua/storage/app/media/zagalna\%2 Oserednya/programy-10-11-klas/2018-

2019/matematika-profilnij-rivenfinal.docx.

2. Syllabus in Mathematics (Algebra and Elements of Analysis and Geometry) for the pupils of the 10-1 $1^{\text {th }}$ grades of the general education institutions (standard level). Retrieved 08.10.2020, from https://mon.gov.ua/storage/app/media/zagalna $\% 2$ Oserednya/programy-10-11-klas/20182019/matematika.-riven-standartu.docx.

3. Syllabus in Mathematics for the pupils of the $10-11^{\text {th }}$ grades of the general education institutions (advanced level). Retrieved 08.10.2020, from https://mon.gov.ua/storage/app/media/zagalna\%2 Oserednya/programy-10-11-klas/20182019/matematika-poglibl-rivenfinal.docx.

4. Computer Studies, syllabus of the optional-obligatory subjects for the pupils of the $10-11^{\text {th }}$ grades of the general education institutions (standard level). Retrieved 08.10.2020, from https://mon.gov.ua/sto rage/app/media/zagalna\%20serednya/programy10-11-klas/2018-2019/informatika-standart-1011.docx.

5. Voitovych, N.V., Naidonova, A.V. (2017). Usage of cloud V54 technologies Google and web 2.0 services in educational process. Methodical recom?endations. Dnipro: Dnipro centre PTOTS. 113 p.

6. Soichuk, R.V. (2016). Information-Communication Technologies in the upbringing process and present coming generation: view on the problem. Innovation theory in upbringing, 4, 220-230.

7. Seidametova, Z.S., Seitvelyeva, S.N. (2011). Cloud services in education. Information technologies in education, 9, 105-111.

8. Kashtan, N.B. (2016). Usage of cloud technologies in educational process of the modern educational establishment. Renovation of the contents, forms and methods of teaching and upbringing in educational establishments, 13(2), 135-137.

9. Kademiia, M.Yu., Shakhina, I.Yu. (2011). Informat-on-communication technologies in the educational process: Teaching guide. Vinnytsia: Planer. 220 p.

\section{SERDIUK Zoia,}

Ph.D in Pedagogy, Associate Professor of Mathematics and Methods of Teaching Mathematics Department, Bohdan Khmelnytsky National University at Cherkasy

\section{KOSTRUB Yuliia,}

Second Year Student of Master's Degree, at the Educational-and-Scientific Institute of Informational-and-Educational Technologies,

Bohdan Khmelnytsky National University at Cherkasy

\section{USAGE OF INFORMATION-AND-COMMUNICATION TECHNOLOGIES IN TEACHING MATHEMATICS ON THE BASIS OF GOOGLE SERVICES}

Summary. Introduction. The task of every Mathematics teacher is to get interested the pupils in Mathematics, to show its beauty, and to help in liking it. One of the means for raising pupils' motivation and interest in learning Mathematics as a science is a well-organized teaching process, which includes new interesting methods and technologies. Nowadays implementation of the computer technologies in the teaching process is an inseparable part of learning Mathematics. By means of them teachers will be able not only to efficiently present educational 
material, but also to show the pupils various possibilities of Mathematics.

The purpose is to prove the necessity of using information-communication technologies (ICT), namely Google services at the Mathematics lessons; to discover the influence of ICT on the pupils' creative development, their attention and cognitive activity; to define the teaching recommendations concerning application of ICT in learning Mathematics.

Methods. Empirical and theoretical methods were used.

Results. At present the efficiency of ICT usage at the Mathematics lessons also depends on using various Internet resources, in particular online services. The developed mathematical site is an opportunity to involve pupils and teachers to interactive cooperation. Under the conditions of the distance learning it is rather useful for raising motivation to learning Mathematics and improving the conditions of the pupils' independent studying as well as a teacher's control over this activity.

Originality. The article deals with the peculiarities of ICT usage on the basis of the Google services in teaching Mathematics. It discovers the efficiency of ICT usage at the Mathematics lessons at school and their influence on the pupils' formation of skills and abilities to correctly use
Google services while studying Mathematics. The author also describes the ways and particular methods for using the technologies at the Mathematics lessons.

Conclusion. In general, information-communication technologies in teaching Mathematics, namely Google services, are a useful and productive teaching technology due to interactivity, flexibility and integration of various types of multimedia educational information and also due to the possibility to take into account the pupils' individual peculiarities. Usage of ICT while teaching Mathematics forms the higher level of the pupils' self-educational skills and abilities, analysis and structuring of the obtained information. Meanwhile the new teaching means allow to naturally combine the information-communication technologies and personal-orientation technologies with the methods of creative and searching activity. Due to this technology it is possible to move the teaching of Mathematics to the higher level.

Keywords: site; information-communication technologies (ICT); web-services; hosting; diagrammes; publications; teaching Mathematics.

Одержано редакиією 09.12.2020 Прийнято до публікаиї̈ 19.12.2020 